Bull. Chem. Soc. Ethiop. 2021, 35(1), 43-59.

(C) 2021 Chemical Society of Ethiopia and The Authors

ISSN 1011-3924

DOI: https://dx.doi.org/10.4314/bcse.v35il.4

Printed in Ethiopia

Online ISSN 1726-801X

\title{
SOLID-STATE SYNTHESIS AND PHYSICO-CHEMICAL CHARACTERIZATION OF MODIFIED SMECTITES USING NATURAL CLAYS FROM BURKINA FASO
}

\author{
Issaka Garikoé ${ }^{1}$, Brahima Sorgho $^{1}$, Boubié Guel $^{1 *}$ and Ingmar Persson ${ }^{2}$ \\ ${ }^{1}$ Laboratoire de Chimie Moléculaire et des Matériaux, Université Joseph Ki-Zerbo, \\ UFR/SEA 03 BP 7021 Ouagadougou 03, Burkina Faso \\ ${ }^{2}$ Department of Molecular Sciences, Swedish University of Agricultural Sciences, P.O. \\ Box 7015, SE-750 07 Uppsala, Sweden
}

(Received November 18, 2019; Revised January 6, 2021; Accepted January 23, 2021)

\begin{abstract}
Solid-state intercalation was applied to prepare organo-smectites using cationic surfactants and natural clays containing smectite at various surfactant/smectite ratios. The surfactants enter the interlayers of smectites causing a swelling of the clays. The used clays were collected in Siétougou and Diabari villages located in the eastern part of Burkina Faso. The solid-state intercalation was successful for all four surfactants applied, $n$ dodecyltrimethylammonium bromide, $\left(n-\mathrm{C}_{12} \mathrm{H}_{25}\left(\mathrm{CH}_{3}\right)_{3} \mathrm{NBr}\right), n$-tetradecyltrimethylammonium bromide, $(n$ $\left.\mathrm{C}_{14} \mathrm{H}_{29}\left(\mathrm{CH}_{3}\right)_{3} \mathrm{NBr}\right), n$-hexadecyltrimethylammonium bromide $\left(n-\mathrm{C}_{16} \mathrm{H}_{33}\left(\mathrm{CH}_{3}\right)_{3} \mathrm{NBr}\right)$ and di- $n$-dodecyldimethylammonium bromide $\left(\left(n-\mathrm{C}_{12} \mathrm{H}_{25}\right)_{2}\left(\mathrm{CH}_{3}\right)_{2} \mathrm{NBr}\right)$ at different levels of the cation exchange capacity (CEC). The synthesized organo-smectites were characterized regarding relative density, structural and textural properties. XRPD data showed a systematic increase of the basal spacing of the unit cell of the smectite up to $>38 \AA$ at 2.0 CEC loading of the surfactant. This increase indicates that the surfactants penetrated into the smectite interlayers with the surfactants being arranged parallel to the layers at low concentrations and almost perpendicular at high ones. FTIR spectra of the organo-smectites showed a decrease in the intensities of the water bands at around 1630 $\mathrm{cm}^{-1}$ and $3400 \mathrm{~cm}^{-1}$, and new specific bands close to $2920 \mathrm{~cm}^{-1}$ and $2850 \mathrm{~cm}^{-1}$ were assigned to the asymmetric and symmetric stretching of $\mathrm{CH}_{2}$ groups of the surfactants, respectively.
\end{abstract}

KEY WORDS: Smectite, Organo-smectite, Surfactant, Intercalation

\section{INTRODUCTION}

Smectite clay minerals are abundant in nature, and they are known to have swelling properties due to their ability to take up water and swell. Surface modification and intercalation of clay minerals have received significant attention as it allows to prepare materials with properties suitable in a wide range of applications at low cost. Several routes to modify clays have been developed to be used in applications as adsorption, ion exchange with inorganic and organic cations, acidification, calcination, and re-aggregation of smectites [1,2]. Generally, the reported scientific papers in this field describe the preparation of the organoclays at laboratory scale using different techniques and chemical conditions, different type of clays, and a range of surfactants as reviewed by Paiva et al. [2]. For modification, e.g. clays quaternary ammonium salts are the most frequently used compounds, but $n$-alkyl-pyrrolidones, maleic anhydride, biomolecules, polymeric quaternary alkylammonium, alkyl-imidazolium and phosphonium salts have also been used for this purpose [2-6]. The areas of application of modified clays are wide including nanocomposites, adsorbents of organic and inorganic pollutants in soil, water, air, etc. [2, 7-9]. Clays and chemically modified clays have extensively been used as adsorbents in environmental systems. The most commonly used clay types in such applications are smectites due to their high CEC, swelling properties, large surface areas, and good adsorption and absorption properties $[2,8,10,11]$..

Intercalation of cationic surfactants into the 2:1 sheets, e.g. smectites changes their surface properties from hydrophilic to hydrophobic $[12,13]$ because of the replacement of hydrated

*Corresponding author. E-mail: boubieguel@yahoo.fr

This work is licensed under the Creative Commons Attribution 4.0 International License 
metal cations between the sheets by cationic surfactants. This is seen through a decrease in the intensities of the water bands in the infrared region at around $1630 \mathrm{~cm}^{-1}$ and $3400 \mathrm{~cm}^{-1}[12,13]$ and new bands related to the surfactants. Transmission and scanning electron microscopy analyses (TEM and SEM, respectively) have been applied to study the macrostructural features of modified clays [14-16]. The TEM analyses showed the packing density of modified clays within the interlayer space, and SEM micrographs showed the difference in surface morphology of untreated and modified clays [14-16]. Thermogravimetry (TG) and differential scanning calorimetry (DSC) have been applied to get information on the thermal behavior of modified clays $[17,18]$. The result of the modification of clays is seen as swelling, thus, the basal spacing between the sheets has increased $[2,14,19]$. As a result, organoclays exhibited better adsorption capacity, e.g. organic contaminants $[2,20,21]$. According to literature, the behavior and properties of organoclays are strongly related to their structure and the chemical properties of the intercalated compound between the sheets $[1,2,14,22]$. Numerous previous studies have shown that the $d_{001}$ spacing of the modified clays is strongly related to the length and number of the alkyl chains and the packing density of the intercalated surfactants of the modified clays [22, $23,24]$.

Modified clays are normally prepared in aqueous solution by cation exchange or solid-state reactions. Organic molecules can be intercalated in dried clay minerals by solid-state reactions without use of solvents and this makes the preparation procedure environmentally friendly and more suitable for industrialization [2, 25]. Solid-state intercalation is therefore to be preferred for modified clays $[25,26]$. However, so far it has been less employed than procedures in aqueous solution $[2,12,14]$. The first solid-state intercalation of alkylammonium cations into clay minerals was reported by Ogawa et al. [25, 27]. Although solid-state intercalation reactions showed several advantages, so far a limited number of studies are reported on the synthesis of modified clays by solid-state reactions $[2,27,28]$. The use of intercalation reactions of organic compounds into clays and clay minerals using solid-state reactions has been described elsewhere $[2,26]$.

In the present work, the solid-state intercalation method was applied to the preparation of organoclays because of simple handling and relatively low cost $[25,26,28]$. Although different types of clays from several regions and suppliers have been used to prepare modified clays, further studies using solid-state intercalation technique to introduce organic compounds into clays and clay minerals are relevant from both scientific and applied point of view. Since the chemical composition of smectite clays varies from one deposit to another, more studies are needed to assess their usefulness as cheap and effective materials with sorption capacity regarding removal of organic contaminants in different environmental applications. To the best of our knowledge, although large deposits of smectite clays, which constitute an important mineral resource, are located in the Eastern part of the country, they have not yet been used for organoclays preparation. These deposits of smectite clays being largely available for the synthesis of modified clays, by intercalating cationic surfactants between the raw clay sheets, a wide range of applications could be considered at low cost in the country.

Four cationic surfactants $n-\mathrm{C}_{12} \mathrm{H}_{25}\left(\mathrm{CH}_{3}\right)_{3} \mathrm{~N}^{+}, n-\mathrm{C}_{14} \mathrm{H}_{29}\left(\mathrm{CH}_{3}\right)_{3} \mathrm{~N}^{+}, \mathrm{n}-\mathrm{C}_{16} \mathrm{H}_{33}\left(\mathrm{CH}_{3}\right)_{3} \mathrm{~N}^{+}$and (n$\left.\mathrm{C}_{12} \mathrm{H}_{25}\right)_{2}\left(\mathrm{CH}_{3}\right)_{2} \mathrm{~N}^{+}$ions as bromide salts have been used in solid-state intercalation reactions with two natural clays of smectite type collected in the Eastern part of Burkina Faso. Clays modified with quaternary alkylammoniums derivatives such as $n$-hexadecyltrimethylammonium and $n$ dodecytrimethyl-ammonium bromides have been reported in a number of studies $[12,21,24$, $29,30,31]$, those intercalated with $n$-tetradecyltrimethylammonium and di- $n$ dodecyldimethylammonium bromides have only been the subject of a limited number of studies $[21,23,24,29,32]$.

The present work was undertaken to investigate the solid-state intercalation of three alkyltrimethylammonium and one di-alkyldimethylammonium cations into two natural smectite clays collected from large deposits located in the Eastern part of Burkina Faso, and the 
subsequent changes of structure and physicochemical properties. The relationship between the $d_{001}$ basal spacing of the modified clays and the length, the number of long alkyl chains in the quaternary alkylammonium ions has been one of the main objectives of this study. Furthermore, the interlayer configuration of intercalated surfactants in the two smectite clays has been elucidated. The variation of the relative density of the organoclays depending on different loading of surfactants has been determined, as this has been scarcely studied [33].

\section{Materials}

\section{EXPERIMENTAL}

The natural clays used in this study are from Siétougou and Diabari villages, denoted AH and DI, respectively, located in the Eastern region of Burkina Faso at the following coordinates, $\mathrm{AH}$ : latitude $=11^{\circ} 54^{\prime} 43.2^{\prime}$ ', longitude $=00^{\circ} 38^{\prime} 22.7^{\prime}$ ', and DI: latitude $=11^{\circ} 51^{\prime} 19.9^{\prime}$ ', longitude $=$ $00^{\circ} 25^{\prime} 08.07^{\prime}$ '.

The used surfactants $n$-dodecyltrimethylammonium bromide $\left(\mathrm{n}-\mathrm{C}_{12} \mathrm{H}_{25}\left(\mathrm{CH}_{3}\right)_{3} \mathrm{NBr},\left(\mathrm{C}_{12}\right)\right), n$ tetradecyltrimethylammonium bromide $\left(\mathrm{n}-\mathrm{C}_{14} \mathrm{H}_{29}\left(\mathrm{CH}_{3}\right)_{3} \mathrm{NBr},\left(\mathrm{C}_{14}\right)\right), n$-hexadecyltrimethylammonium bromide $\left(\mathrm{n}-\mathrm{C}_{16} \mathrm{H}_{33}\left(\mathrm{CH}_{3}\right)_{3} \mathrm{NBr},\left(\mathrm{C}_{16}\right)\right)$ and di- $n$-dodecyldimethylammonium bromide $\left(\left(\mathrm{n}-\mathrm{C}_{12} \mathrm{H}_{25}\right)_{2}\left(\mathrm{CH}_{3}\right)_{2} \mathrm{NBr}, \quad\left(2 \mathrm{C}_{12}\right)\right)$, were purchased from Sigma-Aldrich $(\geq 98 \%$ purity). Silver nitrate $\left(\mathrm{AgNO}_{3}\right.$, Sigma-Aldrich, $\geq 99.8 \%$ purity) was used as purchased to test the presence of the bromide ions in the washing water after treatment of clays with the surfactants.

Organosmectites synthesis

The synthesis of organoclays was undertaken by the following procedure: $4 \mathrm{~g}$ of dried clay (powder size, $\leq 80 \mu \mathrm{m}$ ) and a well-defined amount of surfactant, which represents a level of 0.5 $\mathrm{CEC}, 1.0 \mathrm{CEC}, 1.5 \mathrm{CEC}$ and 2.0 CEC of the used clay, was placed in an agate mortar. The mixture was ground for $10-15 \mathrm{~min}$ to get a homogeneous powder. The treated clays were washed with distilled water to get rid of the bromide ions as checked by the addition of an aqueous solution of silver nitrate, dried at room temperature, and further dried in oven at $100{ }^{\circ} \mathrm{C}$ for 4 hours. The dried modified clays were ground in an agate mortar and stored in closed bottles. The modified clays were labelled as surfactant loading-type of surfactant-original location of the clay, e.g. 0.5 CEC-C $12-\mathrm{AH}$.

\section{Characterization techniques}

Cation exchange capacity was determined by adsorption of copper ethylenediamine $\mathrm{Cu}_{2}(\mathrm{en})_{2}{ }^{2+}$ complex [34]. The CEC values were determined at $34.2 \mathrm{meq} / 100 \mathrm{~g}$ and $25.4 \mathrm{meq} / 100 \mathrm{~g}$ for the raw clays from $\mathrm{AH}$ and $\mathrm{DI}$, respectively.

The relative densities of raw and modified clays are calculated by dividing the mass of the samples by the mass of water in a calibrated $5.0 \mathrm{~mL}$ beaker, weighed in the same way as possible.

The elemental composition of raw clays was determined by using an ICP-OES (Inductively Coupled Plasma Optical Emission Spectroscopy) Optima 7300V HF Perkin Elmer instrument. A well-defined quantity of the sample was mixed with hydrochloric acid and nitric acid in a microwave oven for complete dissolution of the sample and the elementary composition was determined.

X-ray powder diffraction (XRPD) patterns of the samples were recorded between 2 and $62^{\circ}$ with a step size of $0.2^{\circ}$ in scattering angle, $2 \theta$, by a $\theta-\theta$ goniometer as described elsewhere [35] using $\mathrm{Mo}\left(\mathrm{K}_{\alpha 1}\right)$ radiation, $\lambda=0.71073 \AA$.

Fourier transform infrared spectroscopy (FT-IR) was used to characterize the samples in this study. The raw clays, organoclays and pure surfactants were mixed with dry $\mathrm{KBr}$ and pressed

Bull. Chem. Soc. Ethiop. 2021, 35(1) 
into discs with $2 \mathrm{mg}$ of sample and $200 \mathrm{mg} \mathrm{KBr}$ in each tablet. The data were recorded on a Perkin Elmer Spectrum 100 FT-IR spectrometer over the spectral range of $400 \mathrm{~cm}^{-1}-4000 \mathrm{~cm}^{-1}$.

\section{RESULTS AND DISCUSSION}

$X$-ray diffraction of raw clays

The XRD diffractograms of the AH and DI raw clays are shown in Figure 1.

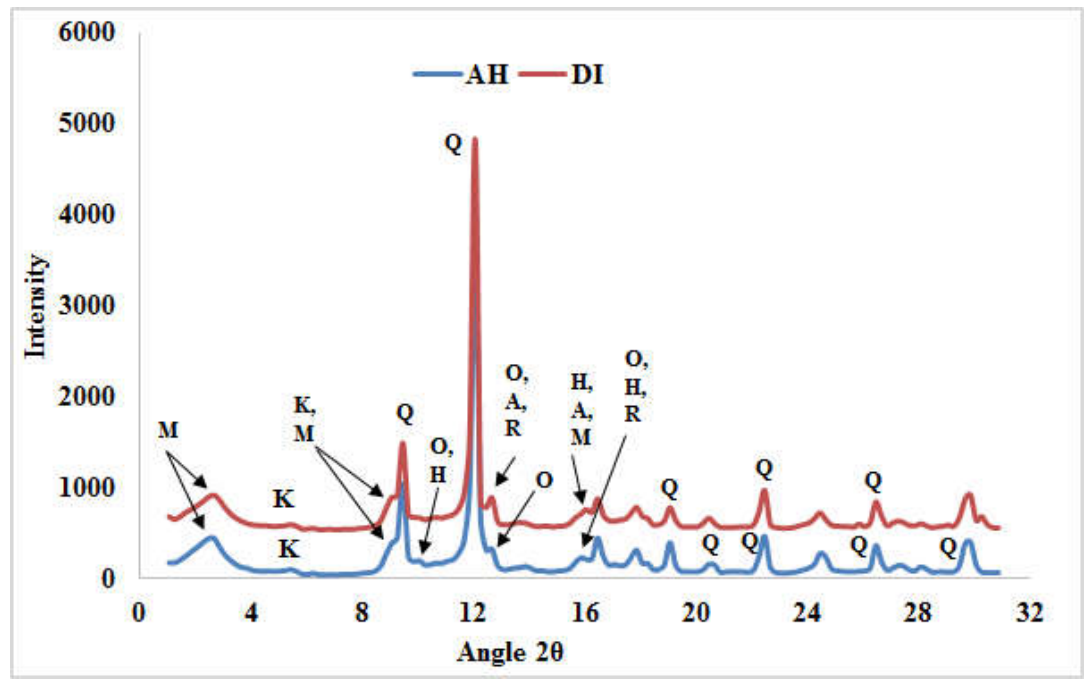

Figure 1. X-ray powder diffraction patterns of $\mathrm{AH}$ and $\mathrm{DI}$ raw clays: $\mathrm{Q}=$ quartz, $\mathrm{M}=$ Montmorillonite, $\mathrm{K}=$ Kaolinite, $\mathrm{H}=$ Hematite, $\mathrm{R}=$ Rutile, $\mathrm{O}=$ orthoclase and $\mathrm{A}=$ Anorthite.

The diffractograms show that the raw clays contain montmorillonite, kaolinite, quartz, anorthite, orthoclase, hematite and rutile. According to literature studies, the $\mathrm{d}_{001}$ basal spacing values reported for Na-montmorillonite are the following: $12.0 \AA$ and $11.78 \AA$, Cubuk et al. [30]; $12.0 \AA$, Caglar et al. [31]; $12.96 \AA$, Tetsuka et al. [36]. In the case of Ca-montmorillonite, the $\mathrm{d}_{001}$ values reported are the following: $15 \AA$, He et al. [29]; $15.72 \AA$, Tetsuka et al. [36]; 15.4 $\AA$, Zhang et al. [37]. In the present study, the $d_{001}$ basal spacing of the smectite phase is seen at $15.3 \AA\left(2.266^{\circ}\right.$ denoted $\mathrm{M}$ in Figure 1$)$. This $\mathrm{d}_{001}$ basal spacing value $(15.3 \AA)$ is closer to the $\mathrm{d}_{001}$ basal spacing of Ca-montmorillonite than the one corresponding to Na-montmorillonite, indicating that the $\mathrm{AH}$ and DI raw clays contain Ca-montmorillonite as the dominant smectite mineral clay. AH and DI clays contain different amounts of montmorillonite with a higher content in AH according to the cation exchange capacity and the XRPD patterns, see above. The presence of montmorillonite, which belongs to the smectite clay group, in the raw clays is advantageous for the intercalation of surfactants as smectite clays have a high cation exchange capacity and large surface areas, which confer strong adsorption/absorption properties. Generally in the literature, Na-montmorillonite, Ca-montmorillonite and bentonite are the mineral clays that are used for the preparation of organoclays. Compared to the existing literature, our study focuses on raw clays containing Ca-montmorillonite, kaolinite, orthoclase and anorthite as mineral phases, with Ca-montmorillonite being the major phase. 


\section{Chemical analysis of raw clays}

The elemental composition of the raw clays was determined and the oxide content is summarized in Table 1. The high values of the $\mathrm{SiO}_{2} / \mathrm{Al}_{2} \mathrm{O}_{3}$ ratio for each raw sample (5.27 for $\mathrm{AH}$ and 5.70 for DI) can be explained by the presence of bentonite (montmorillonite) which has a ratio at around $3.78[38]$ and the presence of a highly free silica.

Table 1. Chemical composition (expressed as mass \%) of the AH and DI clay samples.

\begin{tabular}{|l|l|l|l|l|l|l|l|l|}
\hline \multicolumn{7}{|c|}{ AH clay } \\
\hline Oxide & $\mathrm{Al}_{2} \mathrm{O}_{3}$ & $\mathrm{SiO}_{2}$ & $\mathrm{Fe}_{2} \mathrm{O}_{3}$ & $\mathrm{CaO}$ & $\mathrm{NiO}$ & $\mathrm{P}_{2} \mathrm{O}_{5}$ & $\mathrm{MgO}$ & $\mathrm{SrO}$ \\
\hline Mass \% & 12.7 & 67.1 & 8.54 & 1.12 & 0.03 & 0.04 & 0.96 & 0.01 \\
\hline Oxide & $\mathrm{Cr}_{2} \mathrm{O}_{3}$ & $\mathrm{~K}_{2} \mathrm{O}$ & $\mathrm{SO}_{3}$ & $\mathrm{MnO}$ & $\mathrm{TiO}_{2}$ & $\mathrm{ZrO}_{2}$ & $\mathrm{Na}_{2} \mathrm{O}$ & $\mathbf{S i O}_{2} / \mathbf{A l}_{2} \boldsymbol{O}_{3}$ \\
\hline Mass \% & 0.04 & 0.61 & 0.02 & 0.16 & 1.61 & 0.12 & 0.18 & $\mathbf{5 . 2 7}$ \\
\hline \multicolumn{7}{|c|}{ DI clay } \\
\hline Oxide & $\mathrm{Al}_{2} \mathrm{O}_{3}$ & $\mathrm{SiO}_{2}$ & $\mathrm{Fe}_{2} \mathrm{O}_{3}$ & $\mathrm{CaO}$ & $\mathrm{NiO}$ & $\mathrm{P}_{2} \mathrm{O}_{5}$ & $\mathrm{MgO}$ & $\mathrm{SrO}$ \\
\hline Mass \% & 12.4 & 70.4 & 5.26 & 1.40 & 0.02 & 0.04 & 0.87 & 0.02 \\
\hline Oxide & $\mathrm{Cr}_{2} \mathrm{O}_{3}$ & $\mathrm{~K}_{2} \mathrm{O}$ & $\mathrm{SO}_{3}$ & $\mathrm{MnO}$ & $\mathrm{TiO}_{2}$ & $\mathrm{ZrO}_{2}$ & $\mathrm{Na}_{2} \mathrm{O}$ & $\mathbf{S i O}_{2} / \mathbf{A l}_{2} \boldsymbol{O}_{3}$ \\
\hline Mass \% & 0.02 & 0.77 & 0.02 & 0.13 & 0.93 & 0.10 & 0.59 & $\mathbf{5 . 7 0}$ \\
\hline
\end{tabular}

\section{Relative density measurements}

The relative densities of the samples are summarized in Table 2. These results show a systematic decrease of the relative density with increasing level of surfactant loading which means that the clays swell with the intercalation of the surfactant. The relative density of the organoclays also decreases with the length and number of the long alkyl chains of the surfactants. According to Yevtushenko et al., there is an inverse relationship between porosity and the relative density of soil, which means that the decrease of the relative density causes an increase in soil porosity [39]. Although porosity measurements were not carried out, the decrease of the relative density of the organoclays could indicate that their porosities are higher than the ones of the corresponding untreated samples [39]. The swelling and increased hydrophobicity is certainly the reason for the difficulty to grind the organoclays with high surfactant loading level. Therefore, a simple way to confirm the intercalation of the surfactant molecules into the clays is relative density measurements.

Table 2. Relative densities of the raw and modified clays.

\begin{tabular}{|c|c|c|c|c|c|c|c|c|}
\hline \multirow{3}{*}{$\begin{array}{l}\text { Surfactant } \\
\text { loading level }\end{array}$} & \multicolumn{8}{|c|}{ Surfactants } \\
\hline & \multicolumn{2}{|c|}{$\mathrm{C}_{12}$} & \multicolumn{2}{|c|}{$\mathrm{C}_{14}$} & \multicolumn{2}{|c|}{$\mathrm{C}_{16}$} & \multicolumn{2}{|c|}{$2 \mathrm{C}_{12}$} \\
\hline & $\mathrm{AH}$ & DI & $\mathrm{AH}$ & DI & $\mathrm{AH}$ & DI & $\mathrm{AH}$ & DI \\
\hline $0.0 \mathrm{CEC}$ & 1.55 & 1.50 & 1.55 & 1.50 & 1.55 & 1.50 & 1.55 & 1.50 \\
\hline $0.5 \mathrm{CEC}$ & 1.46 & 1.46 & 1.38 & 1.39 & 1.23 & 1.36 & 1.46 & 1.47 \\
\hline $1.0 \mathrm{CEC}$ & 1.37 & 1.28 & 1.26 & 1.25 & 1.20 & 1.20 & 1.18 & 1.18 \\
\hline $1.5 \mathrm{CEC}$ & 1.34 & 1.27 & 1.28 & 1.19 & 1.15 & 1.13 & 1.09 & 1.20 \\
\hline $2.0 \mathrm{CEC}$ & 1.35 & 1.29 & 1.27 & 1.20 & 1.14 & 1.19 & 1.09 & 1.11 \\
\hline
\end{tabular}


$X$-ray diffraction of the organoclays

The XRPD diffractograms of the DI and AH raw and modified clays prepared at different loading levels (0.5 CEC, 1.0 CEC, 1.5 CEC and 2.0 CEC) using the $\mathrm{C}_{12}, \mathrm{C}_{14}, \mathrm{C}_{16}$ and $2 \mathrm{C}_{12}$ surfactants are shown in Figure 2.

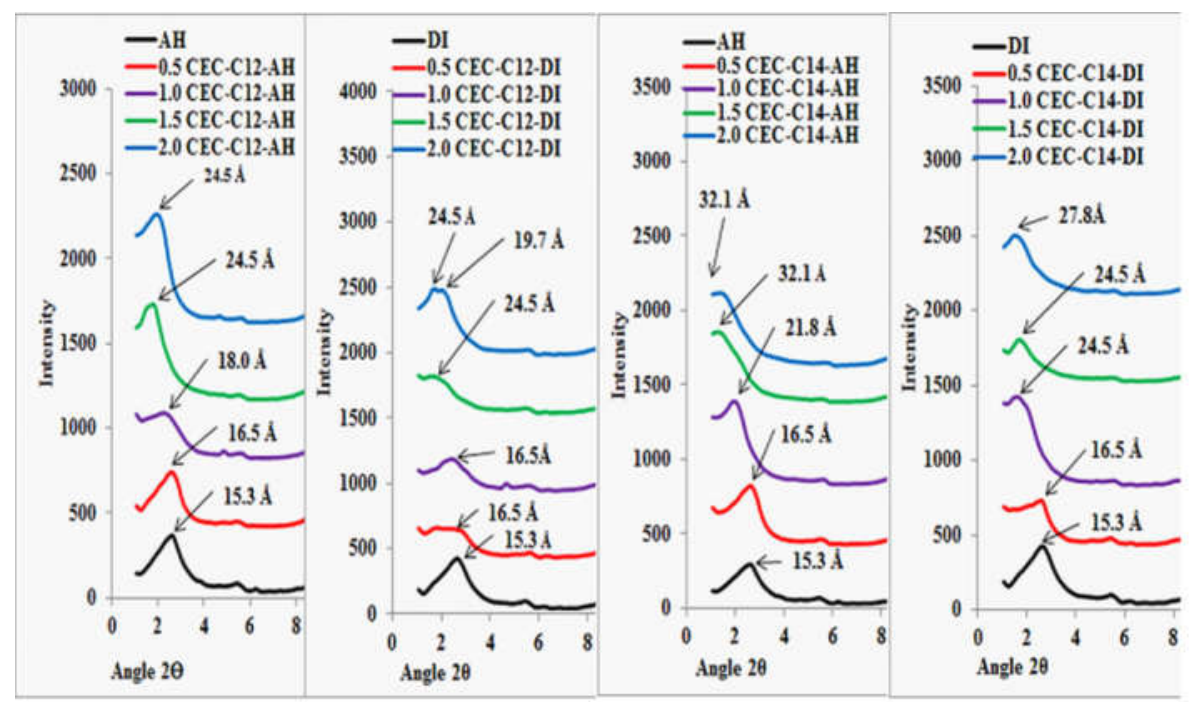

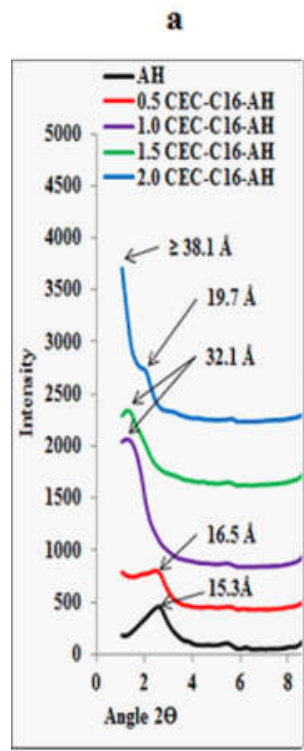

e b

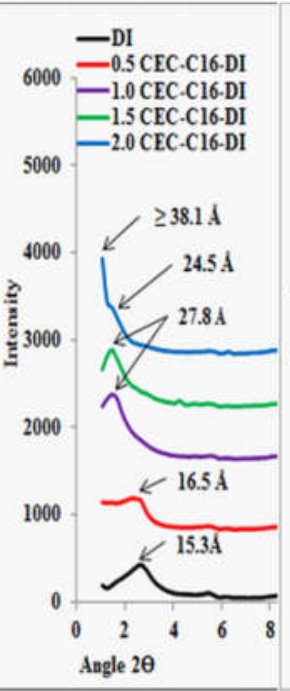

f c
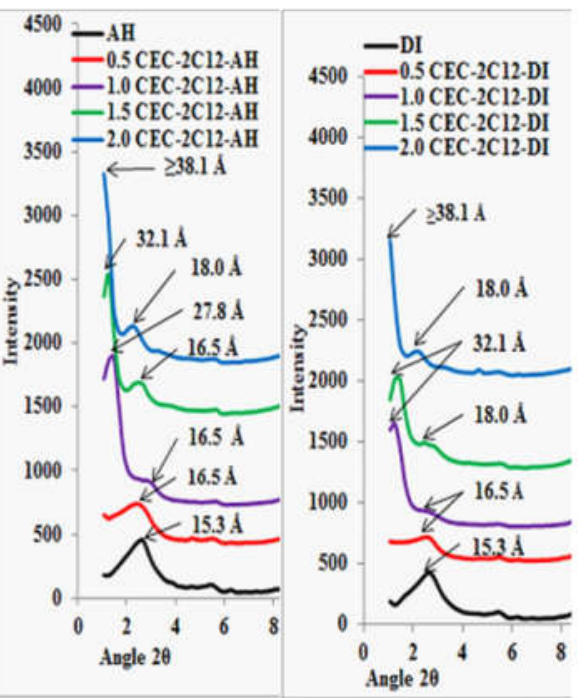

h

Figure 2. X-ray powder diffraction patterns of $\mathrm{AH}$, DI clays and $\mathrm{C}_{12}-\mathrm{AH}, \mathrm{C}_{12}-\mathrm{DI}, \mathrm{C}_{14}-\mathrm{AH}$, $\mathrm{C}_{14}$-DI, $\mathrm{C}_{16}-\mathrm{AH}, \mathrm{C}_{16}$-DI, $2 \mathrm{C}_{12}-\mathrm{AH}$ and $2 \mathrm{C}_{12}$-DI organoclays.

Bull. Chem. Soc. Ethiop. 2021, 35(1) 
The basal spacing information of the modified clays obtained from the XRPD experiments proves the intercalation of the organic surfactant into the clay layers. According to the XRPD patterns of the raw and modified clays, the basal spacing increases with increasing loading of surfactant. This increase shows that the surfactant molecules are intercalated between the layers of the mineral clays and that increased loading increases the basal spacing, $d_{001}$.

The XRPD patterns show also an increasing $d_{001}$ value with increasing length of the long alkyl chain $\left(\mathrm{C}_{12}, \mathrm{C}_{14}\right.$ and $\left.\mathrm{C}_{16}\right)$ and number of long alkyl chains $\left(\mathrm{C}_{12}\right.$ and $\left.2 \mathrm{C}_{12}\right)$, Figure 2 . Furthermore, the increase in the $d_{001}$ values seems to take place in steps with preferred intervals, Figure 2.

The value of the basal spacing $d_{001}$ increases with increasing length of long alkyl chains. The

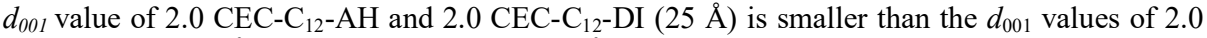
CEC-C $\mathrm{C}_{14}$-AH $(32 \AA)$ and 2.0 CEC-C $\mathrm{C}_{14}$-DI $(28 \AA)$, which are also smaller than the $d_{001}$ values of $2.0 \mathrm{CEC}^{-\mathrm{C}_{16}} \mathrm{-AH}$ and 2.0 CEC-C ${ }_{16}$-DI $(\geq 38 \AA)$. According to Park [24], at $0.5 \mathrm{CEC}$ level loading, the $d_{001}$ value increases marginally with the length of the surfactant: $\mathrm{C}_{12}(14.1 \AA), \mathrm{C}_{14}$ $(14.3 \AA)$ and $\mathrm{C}_{16}(14.4 \AA)$ at a XRD step size of $0.0167^{\circ}$ for $2 \theta$. In principle the same observation is made in this study with the same $d_{001}$ spacing for all applied surfactants at 0.5 CEC loading, Figure 2. This can be explained by the low loading level and the long alkyl chains that are oriented parallel to the sheets, Figures $3 \mathrm{a}$ and $3 \mathrm{~b}$. With increasing loading, length and number of long alkyl chains in the quaternary ammonium ions the $d_{001}$ spacing increases, Figure 2 . This means that the orientation of the intercalated quaternary ammonium ions changes from being parallel with the sheets to become more and more upright with increasing loading, Figure 3 .

At 1.0 CEC loading the increase in $d_{001}$ spacing for $\mathrm{C}_{12}$ and $\mathrm{C}_{14}$ is marginal compared to the $0.5 \mathrm{CEC}$ loading, but significant for $\mathrm{C}_{16}$ and $2 \mathrm{C}_{12}$, Figure 2 . At $1.5 \mathrm{CEC}$ loading the $d_{001}$ spacing for $\mathrm{C}_{12}$ and $\mathrm{C}_{14}$ increase and reach the same values as for the $1.0 \mathrm{CEC}$ loading of $\mathrm{C}_{16}$ and $2 \mathrm{C}_{12}$. However, the latter keep the same $d_{001}$ spacing at $1.5 \mathrm{CEC}$ as at $1.0 \mathrm{CEC}$ loading. At 2.0 CEC loading the $\mathrm{C}_{12}$ and $\mathrm{C}_{14}$ surfactants maintain the loading at $1.5 \mathrm{CEC}$, while for the $\mathrm{C}_{16}$ and $2 \mathrm{C}_{12}$ surfactants a further increase in the $d_{001}$ spacing is observed, Figure 2. These preferred $d_{001}$ spacing's are most likely connected to certain preferred orientations and stacking of the long alkyl chain(s) of the surfactants even though this study cannot give any detailed models for the orientation and stacking of the long alkyl chains of the surfactants applied. Figure 3 shows tentative orientations and stacking of the surfactants with increasing CEC loading. At full intercalation it can be expected that the structure of the surfactants resembles their structure in solid-state. He et al. found that there is an increase when the long alkyl chain number in the quaternary alkylammonium ions increases from one to two in the case of $\mathrm{C}_{12}$ and $\mathrm{C}_{16}$ surfactants [29], as also found in the present study for the $\mathrm{C}_{12}$ surfactant. Indeed, the $d_{001}$ value of 2.0 CEC$\mathrm{C}_{12}$-AH and 2.0 CEC-C $\mathrm{C}_{12}$-DI $(24.5 \AA)$ is smaller than the $d_{001}$ value of $2.0 \mathrm{CEC}-2 \mathrm{C}_{12}$-AH and 2.0 CEC-2 $\mathrm{C}_{12}$-DI ( $\geq 38 \AA$ ), Figure 2. This effect of the level of loading on the $d_{001}$ basal spacing values is in agreement with the previous studies [23, 24, 29, 37, 40, 41]. Cubuk et al. and Caglar et al. $[30,31]$ reported that the basal spacing $\left(d_{001}\right)$ values of modified clays, prepared with $\mathrm{C}_{12}$ and $\mathrm{C}_{16}$ surfactants added between 0.5 CEC and 3.0 CEC increased for each successive level loading (XRD step size $0.026^{\circ}$ for $2 \theta$ ). However, in the present work we found that the basal spacing remains the same in some cases for two successive level loadings. The step size in the present experiment, $0.2^{\circ}$ in $2 \theta$, causes a lower resolution than in previous experiments. Nevertheless, the resolution is sufficient for a basic understanding of the systematic changes in the expansion of the modified clays along the $c$-axis of the montmorillonite unit cell with increasing loading level, length and number of long alkyl chains, of the surfactant.

The XRPD diffractograms indicate that in the case of the $\mathrm{C}_{16}$ and $2 \mathrm{C}_{12}$ surfactants, from 1.0 CEC to 2.0 CEC level loading, the $d_{001}$ basal spacing has two values, Figure 2 . This result is in agreement with the fact that $\mathrm{C}_{16}$ and $2 \mathrm{C}_{12}$ surfactants have more than one molecular arrangement as described by Park [24] and Cubuk et al. [30] for Ca-montmorillonite interlayers. This may 
depend on different availability for loading of different particles. The peaks related to $d_{001}$ spacing are shifted to lower Bragg angles for all modified clay samples with increased surfactant loading. This variation in the intercalation spacing is systematic with length, number of long alkyl chains and level of surfactant loading applied for the Ca-montmorillonite clays, which is in agreement with the previous studies $[23,24,30,42]$. The increase of the $\mathrm{d}_{001}$ basal spacing at the surfactant intercalation also sustains the decrease of the relative density.

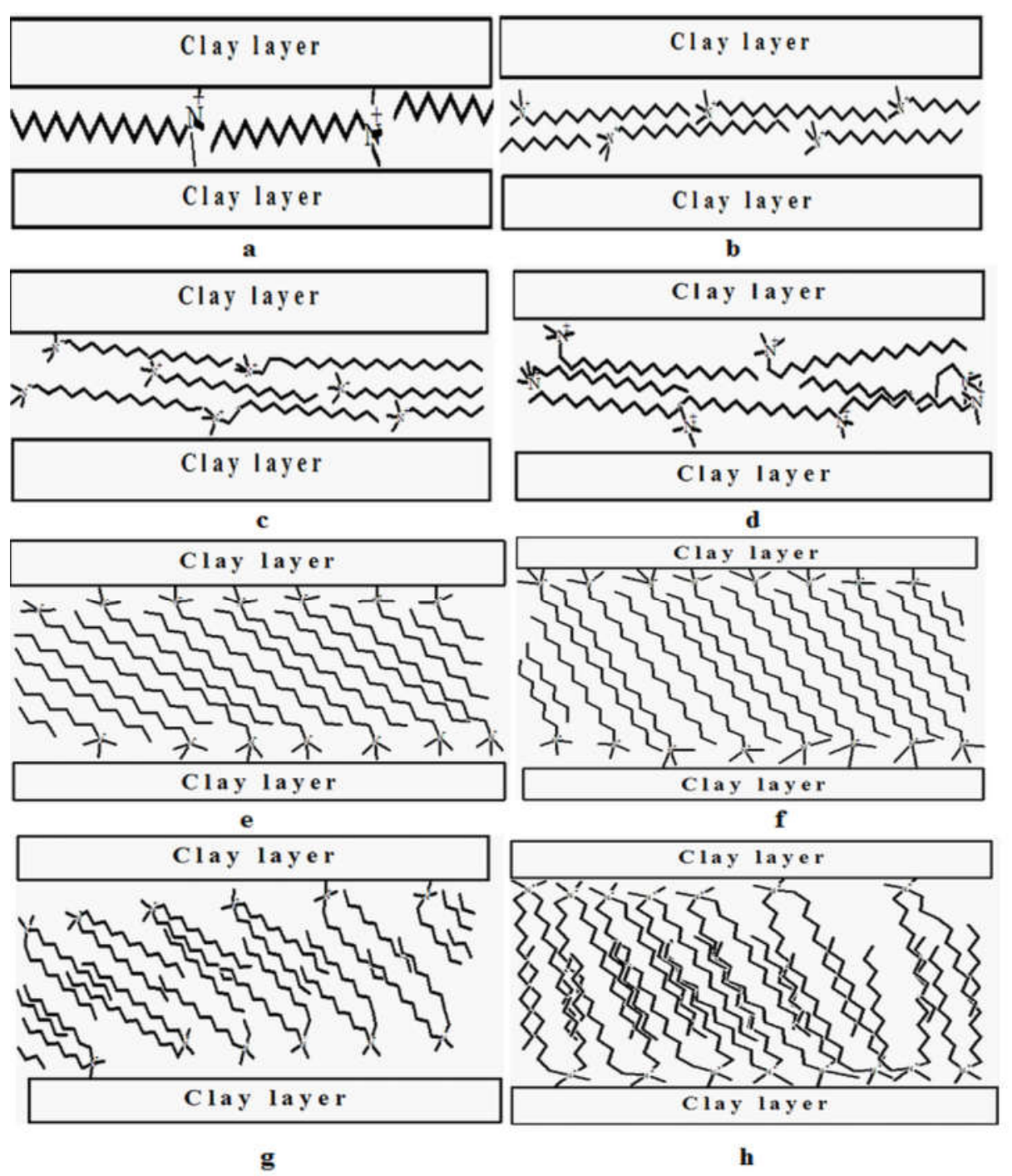

Figure 3. Surfactant molecules orientations into the interlayer space: arrangements (a) monolayer, (b) bilayers, and (c, d) pseudo-trilayers and (e, f and g, h) paraffin-type for one and two long alkyl chains, respectively [45]. 
The orientation of the surfactants depends most likely on the quantity and the arrangement and orientation of the surfactant in the interlayer. The structure of the adsorbed surfactant layer in the interlayers of smectite is most likely also affected by the charge distribution and chemical composition of the smectite.

Considering the interlayer expansions and the molecular dimensions of the surfactants, tentative arrangements of the surfactant molecules between the 2:1 sheets of the smectite have been distinguished. The expansion of the smectite evaluated by deducting the thickness of the smectite layer structure (tetrahedral-octahedral-tetrahedral) 2:1 unit $(9.7 \AA$ ) $[30,31,43]$ from basal spacing of $0.5 \mathrm{CEC}$ organoclays samples is $6.8 \AA$. The molecular dimensions are approximately $3.8 \AA$ in width and $18.0 \AA$ in length for $\mathrm{C}_{12} \mathrm{H}_{25}\left(\mathrm{CH}_{3}\right)_{3} \mathrm{~N}^{+}, 4.0 \AA$ in width and 20.8 $\AA$ in length for $\mathrm{C}_{14} \mathrm{H}_{29}\left(\mathrm{CH}_{3}\right)_{3} \mathrm{~N}^{+}$and $4.2 \AA$ in width and $23.5 \AA$ in length for $\mathrm{C}_{16} \mathrm{H}_{33}\left(\mathrm{CH}_{3}\right)_{3} \mathrm{~N}^{+}$ when the long alkyl chain for each surfactant is parallel to the plan of smectite clay $[30,31,43]$. Regarding the interlayer expansion of $6.8 \AA$ for all modified clays at $0.5 \mathrm{CEC}$ loading of $\mathrm{AH}$ and DI smectites and the molecular sizes of $\mathrm{C}_{12}, \mathrm{C}_{14}$ and $\mathrm{C}_{16}$, it can be concluded that the surfactant molecules are located as a lateral monolayer arrangement. The interlayer distance and basal spacing of modified smectites at 0.5 CEC surfactant loading in this work are in agreement with previous investigations showing that $\mathrm{C}_{12}, \mathrm{C}_{14}$ and $\mathrm{C}_{16}$ cations are inserted laterally in a monolayer arrangement [29, 30, 31, 43], Figure 3a.

The expansion of the interlayers when increasing the surfactant loading from 1.0 CEC to 2.0 CEC levels are $8.3 \AA, 10.0 \AA, 12.1 \AA, 14.8 \AA, 18.1 \AA, 22.4 \AA$ and more than $28.3 \AA$ depending on the raw clay and/or the surfactant, Figures 3. Considering the molecular size of the surfactant, the expansion values, $8.3 \AA$ and $10.0 \AA$, correspond to a bilayer arrangement of surfactant molecules with an angle which depends on the interaction between the surfactant molecules and the clay layers, the chemical composition of the clay and the structure of the surfactant. The $d_{001}$ basal spacing values corresponding to this arrangement are $18.0 \AA$ and 19.7 $\AA$. For $12.1 \AA$ and $14.8 \AA$ as expansion values, the molecular orientation of the carbon alkyl chain is contained in an oblique plan and the arrangement of the surfactant molecule reaches a pseudo-trilayer arrangement. In case the expansions are 18.1 $\AA, 22.4 \AA$ and more than $28.4 \AA$, the alkyl chain arrangement is paraffin-type and approximate to the alternate antiparallel packing between the clay layer as found in the crystal structures in solid bromide salts of the surfactants $\mathrm{C}_{12}, \mathrm{C}_{14}$ and $\mathrm{C}_{16}$ [44]. The $d_{001}$ basal spacing values corresponding to the paraffintype arrangement are $27.8 \AA, 32.1 \AA$ and more than $38 \AA$. Therefore, the angle between the clay layers and the plane of the surfactant molecules approaches $90^{\circ}$. These arrangements of the long alkyl chains in the organoclays are similar to those proposed by Lagaly et al. [45].

A general decrease in intensity of the diffraction peaks with increasing loading of surfactants, Figure 3, strongly indicates decreasing crystallinity of organoclays with increase length of the c-axis due to the surfactant loading.

\section{Fourier transform infrared (FTIR) spectroscopy of organoclays}

The FTIR spectra of raw clays and modified clays prepared at 0.5 CEC, 1.0 CEC, 1.5 CEC and 2.0 CEC level loadings of $\mathrm{C}_{12}, \mathrm{C}_{14}, \mathrm{C}_{16}$ and $2 \mathrm{C}_{12}$ surfactants, and pure surfactants are shown in Figures 4-7.

In all these FTIR spectra, the $\mathrm{H}-\mathrm{O}-\mathrm{H}$ bending bands of water molecules adsorbed on raw and modified clays appear at ca. $1600 \mathrm{~cm}^{-1}$. The peak at $3622 \mathrm{~cm}^{-1}$ for the raw clays is assigned to $\mathrm{OH}$ stretching vibrations of the structural hydroxyl group, and the band around $3420 \mathrm{~cm}^{-1}$ is assigned to water molecules adsorbed between the layers of the clay. Madejová et al. assigned the peaks at $3694 \mathrm{~cm}^{-1}$ and $3620 \mathrm{~cm}^{-1}$ to $\mathrm{AlMg}-\mathrm{OH}$ and $\mathrm{Al}_{2}-\mathrm{OH}$ vibrations, respectively. Those bands are normally assigned to stretching vibrations of hydroxyl groups coordinated to octahedral cations in montmorillonite or kaolinite [46-48]. Moreover the absorption peaks seen 
at $3620 \mathrm{~cm}^{-1}$ on the raw clays and oganoclays are typical for smectites with high amount of $\mathrm{Al}$ in the octahedra [46].

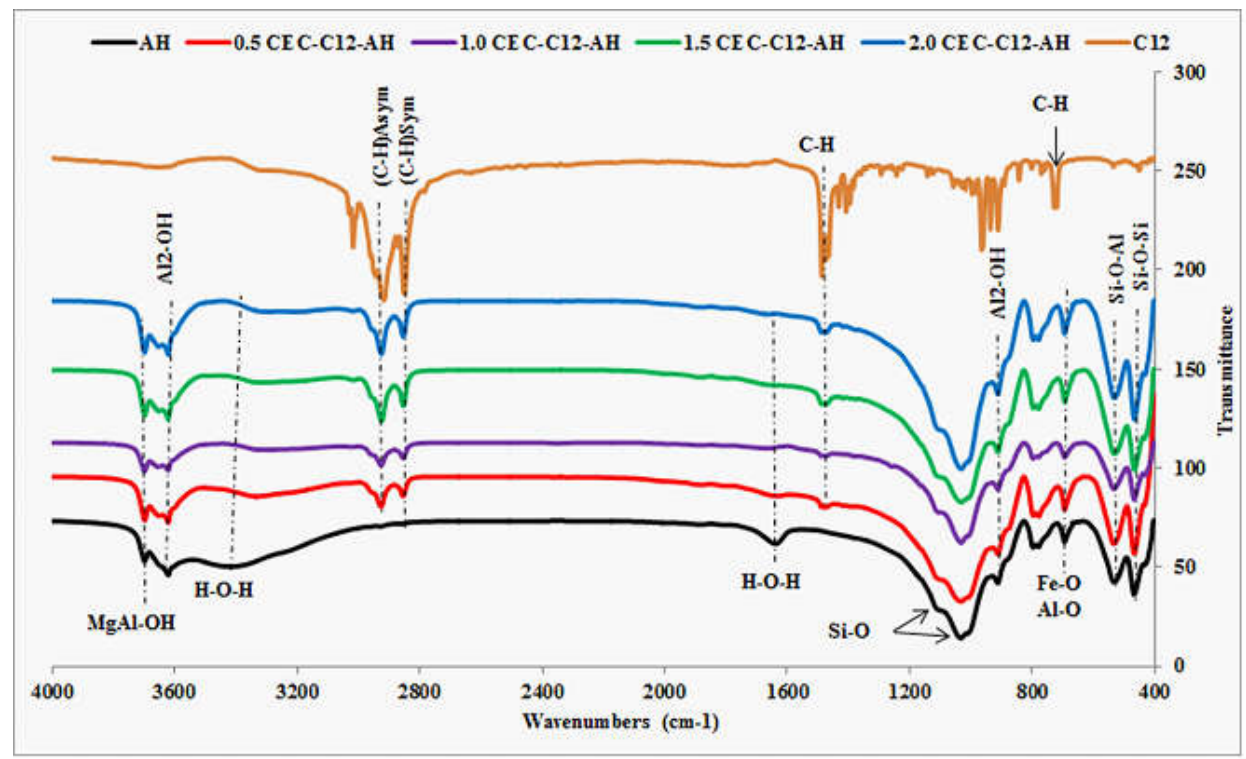

a

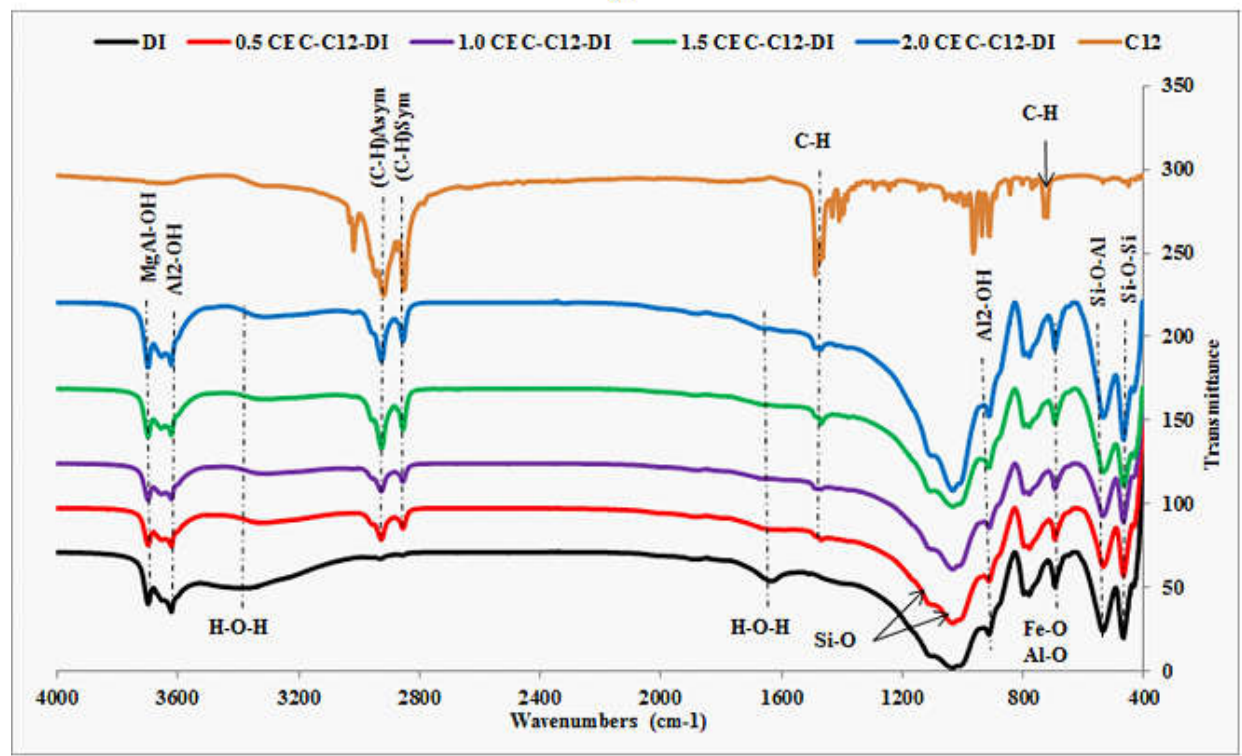

b

Figure 4. FTIR spectra of $\mathrm{AH}$ and DI raw clays, and $\mathrm{C}_{12}-\mathrm{AH}$ and $\mathrm{C}_{12}$-DI organoclays. 

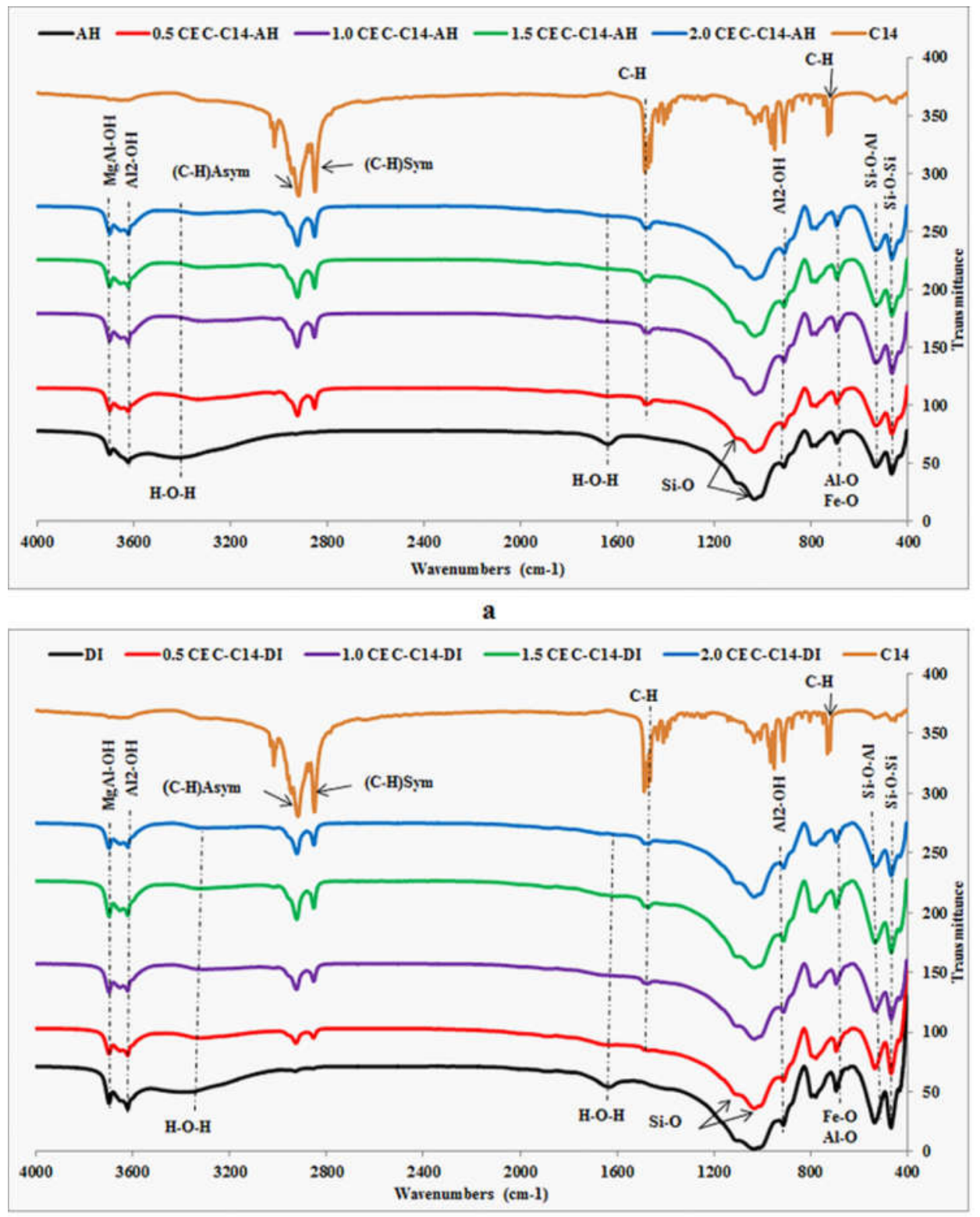

b

Figure 5. FTIR spectra of $\mathrm{AH}$ and DI raw clays, and $\mathrm{C}_{14}-\mathrm{AH}$ and $\mathrm{C}_{14}$-DI organoclays. 

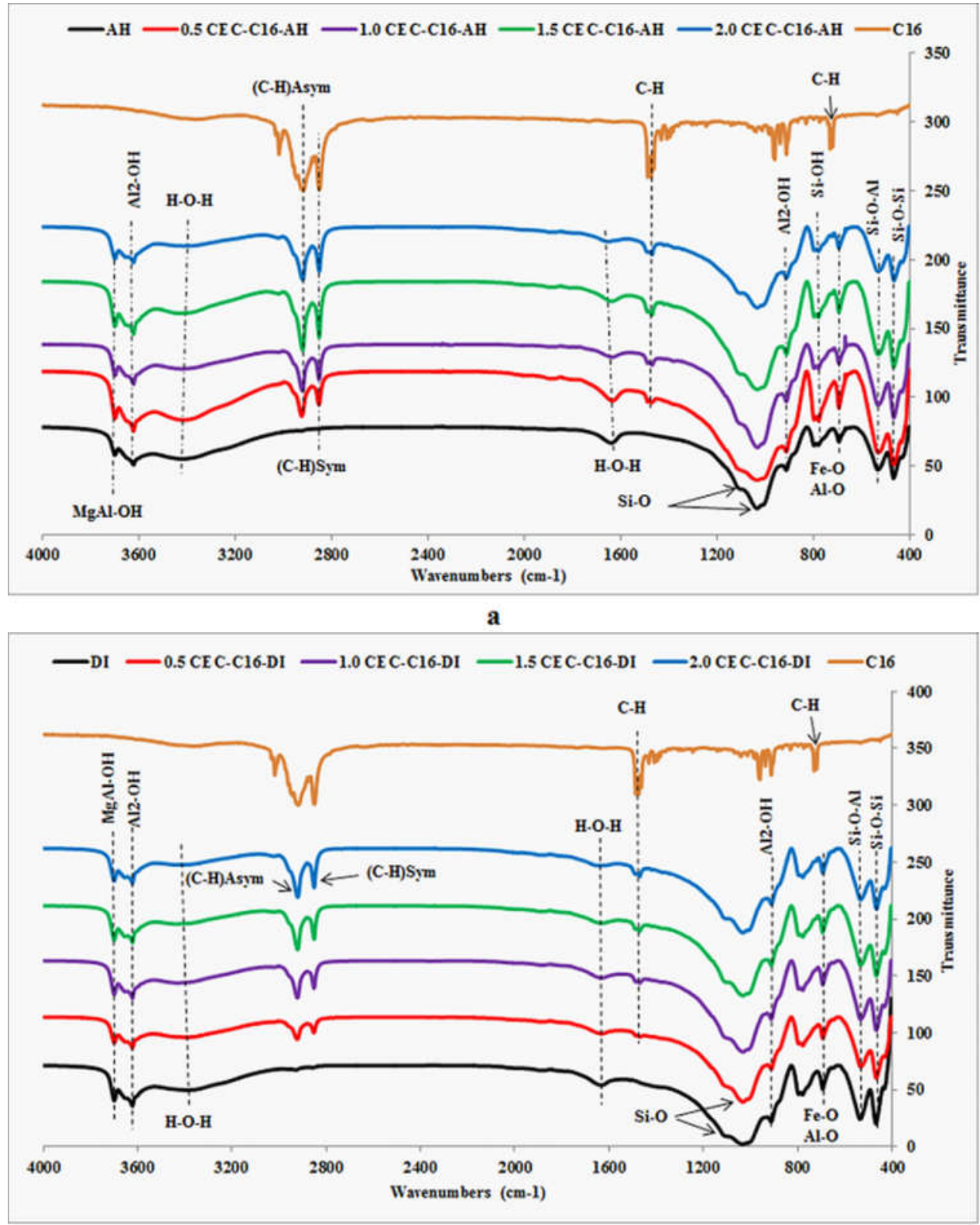

b

Figure 6. FTIR spectra of $\mathrm{AH}$ and DI raw clays, and $\mathrm{C}_{16}-\mathrm{AH}$ and $\mathrm{C}_{16}$-DI organoclays. 


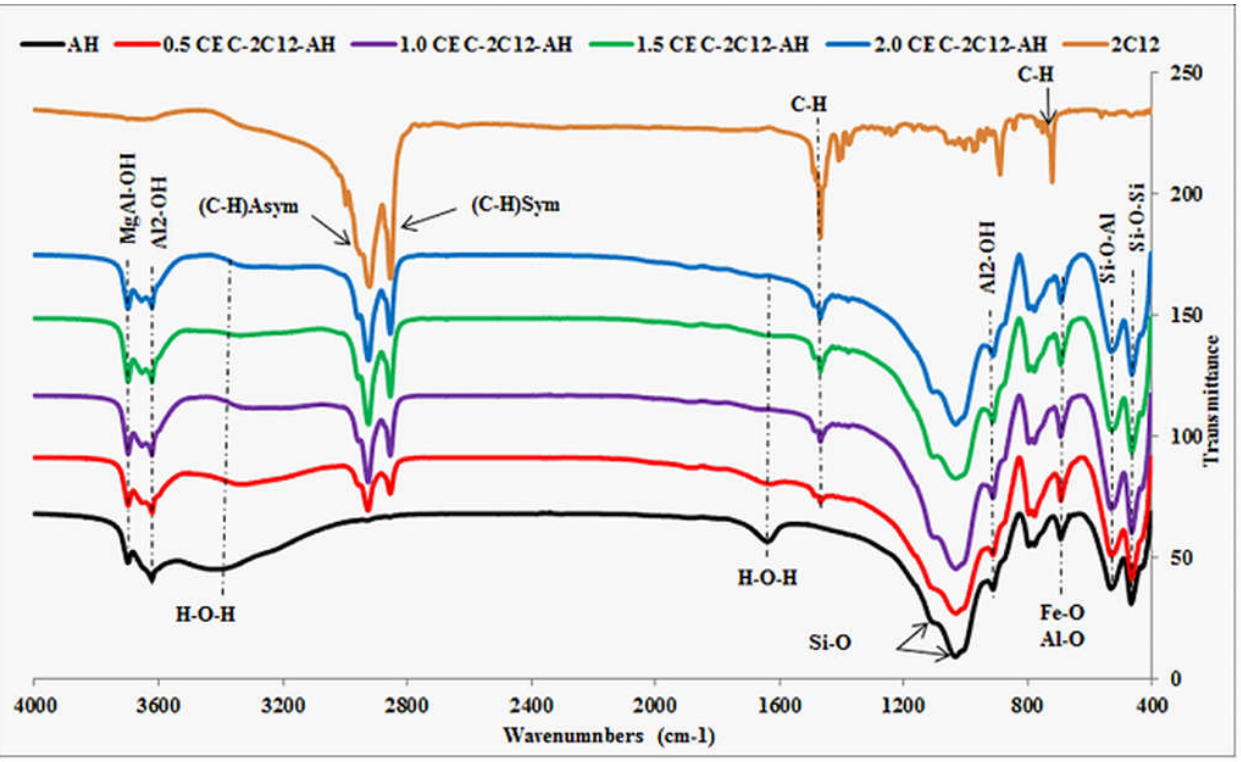

a

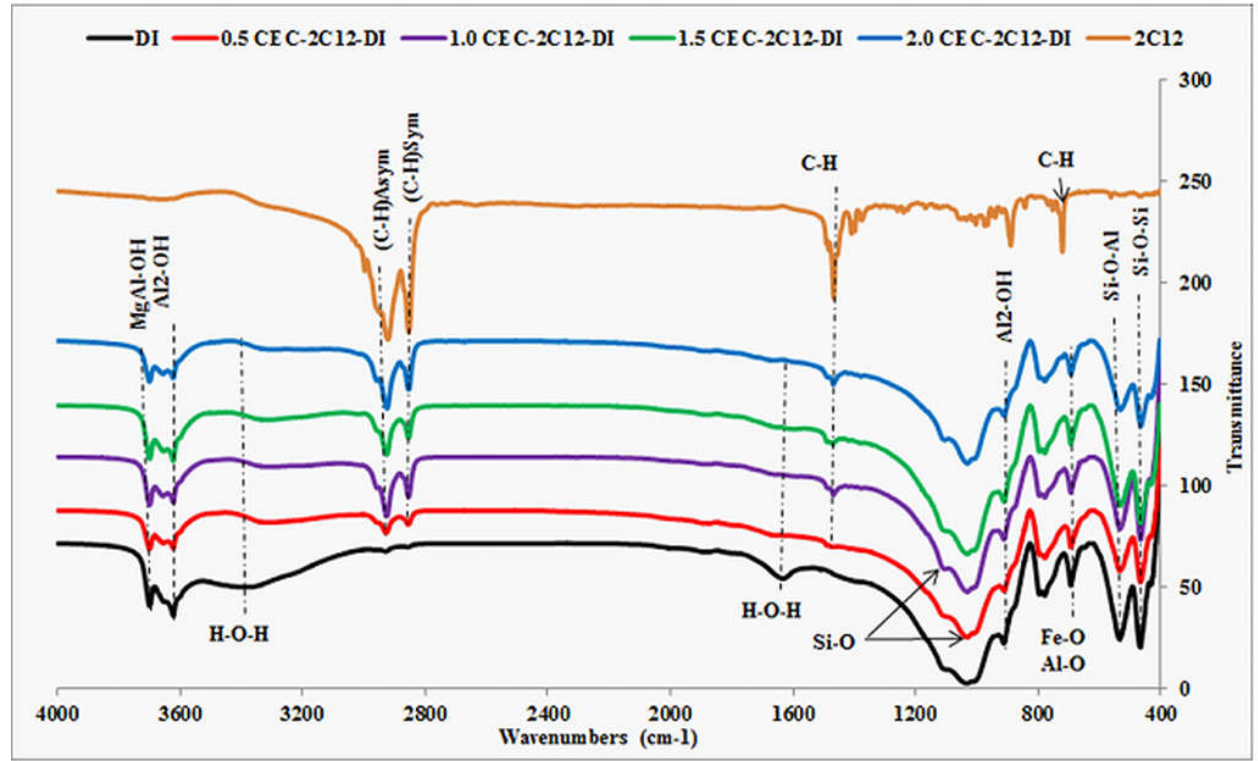

b

Figure 7. FTIR spectra of $\mathrm{AH}$ and $\mathrm{DI}$ raw clays, and $2 \mathrm{C}_{12}-\mathrm{AH}$ and $2 \mathrm{C}_{12}$-DI organoclays.

All FTIR spectra contain bands attributed to Si-O stretching at $1100 \mathrm{~cm}^{-1}$ and $\mathrm{Si}-\mathrm{O}$ in-plane bending at $470 \mathrm{~cm}^{-1}$ [47]. The absorption peaks at $913 \mathrm{~cm}^{-1}$ and $536 \mathrm{~cm}^{-1}$ are assigned to $\mathrm{Al}_{2-} \mathrm{OH}$ bending vibration and Al-O-Si deformations of raw clays, respectively [47, 48]. The peaks observed around $694 \mathrm{~cm}^{-1}$ are assigned to $\mathrm{Fe}-\mathrm{O}$ or Al-O out of plane bending vibrations [47]. 
The $\mathrm{CH}_{2}$ asymmetric stretching bands are slightly shifted to lower wavenumbers upon intercalation of the $\mathrm{C}_{12}, \mathrm{C}_{14}, \mathrm{C}_{16}$ and $2 \mathrm{C}_{12}$ surfactants from $2927 \mathrm{~cm}^{-1}$ to $2920 \mathrm{~cm}^{-1}$ depending on $\mathrm{AH}$ or DI raw clays, and surfactant loading, 0.5 CEC to 2.0 CEC level. Furthermore, the wavenumber of the symmetric $\mathrm{CH}_{2}$ stretching mode is shifted from $2855 \mathrm{~cm}^{-1}$ to $2850 \mathrm{~cm}^{-1}$ seen in the modified clays, Figures 4-7. When the surfactant loading level increases, the wavenumbers of asymmetric and symmetric $\mathrm{CH}_{2}$ stretching bands of surfactants in the modified clays approach the wavenumbers of the pure surfactant. This further indicates that the alkyl chains are packed in a similar way as in the pure surfactant when the intercalation approaches saturation. According to Kamitori et al. [44], Silva et al. [49] and Campanelli and Scaramuzza [50], the molecular arrangements of $\mathrm{C}_{12}, \mathrm{C}_{14}$ and $\mathrm{C}_{16}$ alkyl chains are as parallel as possible within a layer and antiparallel in alternate layers in the pure surfactant. The infrared spectroscopy data support that arrangement of alkyl chains in the organoclays changes gradually from being parallel with clay sheets at low surfactant loading to standing in a similar or identical way as the pure surfactants at high loading as proposed in previous studies [12, 13, 24].

The wavenumbers of asymmetric and symmetric stretching modes of $\mathrm{CH}_{2}$ of the pure surfactant molecules and the modified clays are summarized in the Table 3 . The frequency and the intensity of the asymmetric and symmetric stretching bands of $\mathrm{CH}_{2}$ change with the length and the number of long alkyl chains as well as with level of loading. However, the $\mathrm{CH}_{2}$ scissoring and rocking vibrations seen at $1473 \mathrm{~cm}^{-1}$ and $731 \mathrm{~cm}^{-1}$, respectively [30], seem to be independent of the length of alkyl chain and level of loading.

Moreover, the additional weak band, which is seen between $3670 \mathrm{~cm}^{-1}$ and $3700 \mathrm{~cm}^{-1}$ on the raw clay spectra, increases with surfactants molecules intercalation. This is related to the insertion of the surfactants molecules into the Ca-montmorillonite interlayers. It is observed that the band intensities at $3420 \mathrm{~cm}^{-1}$ and $1635 \mathrm{~cm}^{-1}$ decreased progressively with the surfactant loading level due to the intercalation of the quaternary alkylammonium cations and this causes that the hydrophilic properties of raw clays change to hydrophobic ones [30, 31, 46]. The FTIR spectra support the model of intercalation of surfactants between the sheets in clays as described above, Figure 3.

Table 3. Wavenumbers variation of $\mathrm{CH}_{2}$ asymmetric and symmetric stretching mode in $\mathrm{AH}$ and DI modified clays.

\begin{tabular}{|c|c|c|c|c|c|c|c|c|}
\hline & \multicolumn{8}{|c|}{ AH clay } \\
\hline & \multicolumn{8}{|c|}{ Surfactants and wavenumbers $\left(\mathrm{cm}^{-1}\right)$ of asymmetric and symmetric $\mathrm{CH}_{2}$ stretching } \\
\hline \multirow[t]{2}{*}{ Loading level } & \multicolumn{2}{|c|}{$\mathrm{C}_{12}$} & \multicolumn{2}{|c|}{$\mathrm{C}_{14}$} & \multicolumn{2}{|c|}{$\mathrm{C}_{16}$} & \multicolumn{2}{|c|}{$2 \mathrm{C}_{12}$} \\
\hline & $\mathrm{CH}_{2}$ asym & $\mathrm{CH}_{2} \mathrm{sym}$ & $\mathrm{CH}_{2}$ asym & $\mathrm{CH}_{2} \mathrm{sym}$ & $\mathrm{CH}_{2}$ asym & $\mathrm{CH}_{2} \mathrm{Sym}$ & $\mathrm{CH}_{2}$ asym & $\mathrm{CH}_{2} \mathrm{Sym}$ \\
\hline $0.5 \mathrm{CEC}$ & 2926 & 2855 & 2923 & 2853 & 2923 & 2852 & 2925 & 2854 \\
\hline $1.0 \mathrm{CEC}$ & 2926 & 2854 & 2923 & 2852 & 2921 & 2851 & 2924 & 2854 \\
\hline 1.5 CEC & 2925 & 2854 & 2922 & 2852 & 2920 & 2851 & 2924 & 2853 \\
\hline 2.0 CEC & 2925 & 2854 & 2921 & 2851 & 2920 & 2850 & 2921 & 2853 \\
\hline \multicolumn{9}{|c|}{ DI clay } \\
\hline \multicolumn{9}{|c|}{ Surfactants and wavenumbers $\left(\mathrm{cm}^{-1}\right)$ of asymmetric and symmetric $\mathrm{CH}_{2}$ stretching } \\
\hline \multirow[t]{2}{*}{ Loading leve } & \multicolumn{2}{|c|}{$\mathrm{C}_{12}$} & \multicolumn{2}{|c|}{$\mathrm{C}_{14}$} & \multicolumn{2}{|c|}{$\mathrm{C}_{16}$} & \multicolumn{2}{|c|}{$2 \mathrm{C}_{12}$} \\
\hline & $\mathrm{CH}_{2}$ asym & $\mathrm{CH}_{2} \mathrm{sym}$ & $\mathrm{CH}_{2}$ asym & $\mathrm{CH}_{2} \mathrm{sym}$ & $\mathrm{CH}_{2} \mathrm{asym}$ & $\mathrm{CH}_{2} \mathrm{sym}$ & $\mathrm{CH}_{2}$ asym & $\mathrm{CH}_{2} \mathrm{sym}$ \\
\hline $0.5 \mathrm{CEC}$ & 2926 & 2855 & 2926 & 2854 & 2923 & 2852 & 2927 & 2855 \\
\hline $1.0 \mathrm{CEC}$ & 2926 & 2855 & 2924 & 2853 & 2922 & 2851 & 2925 & 2855 \\
\hline $1.5 \mathrm{CEC}$ & 2924 & 2854 & 2923 & 2852 & 2921 & 2851 & 2925 & 2854 \\
\hline 2.0 CEC & 2924 & 2854 & 2922 & 2852 & 2920 & 2851 & 2924 & 2854 \\
\hline $\begin{array}{c}\text { Pure } \\
\text { surfactants }\end{array}$ & 2918 & 2850 & 2918 & 2849 & 2919 & 2849 & 2921 & 2853 \\
\hline
\end{tabular}




\section{CONCLUSION}

Two natural clays from Burkina Faso containing Ca-montmorillonite as main clay type were successfully intercalated by cationic alkyltrimethylammoniums $\left(n-\mathrm{C}_{12} \mathrm{H}_{25}\left(\mathrm{CH}_{3}\right)_{3} \mathrm{~N}^{+}\right.$, n$\mathrm{C}_{14} \mathrm{H}_{29}\left(\mathrm{CH}_{3}\right)_{3} \mathrm{~N}^{+}$and $\left.n-\mathrm{C}_{16} \mathrm{H}_{33}\left(\mathrm{CH}_{3}\right)_{3} \mathrm{~N}^{+}\right)$and di-alkyldimethylammonium $\left(\left(n-\mathrm{C}_{12} \mathrm{H}_{25}\right)_{2}\left(\mathrm{CH}_{3}\right)_{2} \mathrm{~N}^{+}\right)$ using solid-state reaction methodology. Relative density measurements show that the relative density of the organoclays decreases with increasing surfactant loading. Thus, the natural clays swell substantially at treatment with surfactants. The increase of the $d_{001}$ spacing shown by XRPD proved the swelling of layers by intercalation of the surfactants. The value of basal spacing reaches $25 \AA$ for modified clays treated with $\mathrm{C}_{12}, 32 \AA$ for those treated with $\mathrm{C}_{14}$, and more than $38 \AA$ for those treated with $\mathrm{C}_{16}$ and $2 \mathrm{C}_{12}$ at $2.0 \mathrm{CEC}$ loading level of the surfactant. The IR spectra showed the $\mathrm{CH}_{2}$ asymmetric and symmetric stretching bands at around $2920 \mathrm{~cm}^{-1}$ and $2850 \mathrm{~cm}^{-1}$, respectively, proving successful intercalation. FTIR spectra showed that the wavenumbers of asymmetric and symmetric stretching vibrations of the surfactants in organoclays decrease and approach the values observed for the pure surfactants with increasing surfactant level. The intercalation of the quaternary alkylammonium cations into the clays interlayers causes that the hydrophilic properties of raw clays change to hydrophobic and organophilic. The solid-state intercalation of alkyltrimethylammonium and di-alkyldimethylammonium cations is an effective and simple method to prepare useful modified clays for environmental applications.

\section{ACKNOWLEDGMENTS}

This work was sponsored by the International Science Programme (ISP, Uppsala, Sweden). Their financial support is gratefully acknowledged. Issaka Garikoé would like to thank the ISP for receiving fellowship to stay at the Swedish University of Agricultural Sciences within the framework of the IPICS/BUF: 02 Project. Dr. Gulaim Seisenbaeva is acknowledged for allowing us to use the FTIR instrument at the Department of Molecular Sciences, Swedish University of Agricultural Sciences.

\section{REFERENCES}

1. Bergaya, F.; Lagaly G. Surface modification of clay minerals. Appl. Clay Sci. 2001, 19, 1-3.

2. Betega de Paiva, L.; Morales, A.R.; Valenzuela Díaz, F.R. Organoclays: Properties, preparation and applications. Appl. Clay Sci. 2008, 42, 8-24.

3. Patel, H.A.; Somani, R.S; Bajaj, H.C.; Jasra, R.V. Preparation and characterization of phosphonium montmorillonite with enhanced thermal stability. Appl. Clay Sci. 2007, 35, 194-200.

4. Simionca, I.M.; Arvinte, A.; Pinteala, M. High crown ether-based structures for sensitive electrochemical detection. High Perform. Polym. 2015, 27, 669-675.

5. Öztürk, N.; Tabak, A.; Akgöl, S.; Denizli, A. Newly synthesized bentonite-histidine (BentHist) micro-composite affinity sorbents for IgG adsorption. Colloids Surf. A Physicochem. Eng. Asp. 2007, 301, 490-497.

6. Gopinath, S.; Sugunan, S. Enzymes immobilized on montmorillonite K10: Effect of adsorption and grafting on the surface properties and the enzyme activity. Appl. Clay Sci. 2007, 35, 67-75.

7. Mishra, A.K.; Allauddin, S.; Narayan, R.; Aminabhavi, T.M.; Raju, K.V.S.N. Characterization of surface-modified montmorillonite nanocomposites. Ceram. Int. 2012, 38, 929-934.

8. Lee, S.Y.; Kim, S.J.; Chung, S.Y.; Jeong, C.H. Sorption of hydrophobic organic compounds onto organoclays. Chemosphere 2004, 55,781-785.

9. Bhattacharyya, K.G.; Gupta, S.S. Adsorption of a few heavy metals on natural and modified 
kaolinite and montmorillonite: A review. Adv. Colloid Interface Sci. 2008, 140, 114-131.

10. Chatterjee, A.; Ebina, T.; Onodera, Y.; Mizukami, F. Effect of exchangeable cation on the swelling property of 2:1 dioctahedral smectite a periodic first principle study. J. Chem. Phys. 2004, 120, 3414-3424.

11. Guimarães, A.M.F.; Ciminelli, V.S.T.; Vasconcelos, W.L. Smectite organofunctionalized with thiol groups for adsorption of heavy metal ions. Appl. Clay Sci. 2009, 42, 410-414

12. Li, Z.; Jiang, W-T; Hong, H. An FTIR investigation of hexadecyltrimethylammonium intercalation into rectorite. Spectrochim. Acta A Mol. Biomol. Spectrosc. 2008, 71, 15251534.

13. He, H.; Ray, F.L.; Jianxi, Z. Infrared study of HDTMA (+) intercalated montmorillonite. Spectrochim. Acta A Mol. Biomol. Spectrosc. 2004, 60, 2853-2859.

14. Yang, Q.; Gao, M.; Luo, Z.; Yang, S. Enhanced removal of bisphenol A from aqueous solution by organo-montmorillonites modified with novel Gemini pyridinium surfactants containing long alkyl chain. Chem. Eng. J. 2016, 285, 27-38.

15. Khaorapapong, N.; Khumchoo, N.; Ogawa, M. Preparation of copper oxide in smectites. Appl. Clay Sci. 2015, 104, 238-244.

16. Khumchoo, N.; Khaorapapong, N.; Ogawa, M. Formation of zinc oxide particles in cetyltrimethylammonium-smectites. Appl. Clay Sci. 2015, 105-106, 236-242.

17. Önal, M.; Sarikaya, Y. Thermal characterization of methyltributylammonium-smectites. $J$. Therm. Anal. Calorim. 2008, 91, 835-839.

18. Hedley, C.B.; Yuan, G.;Theng, B.K.G. Thermal analysis of montmorillonites modified with quaternary phosphonium and ammonium surfactants. Appl. Clay Sci. 2007, 35, 180-188.

19. Maghear, A.; Tertiş M.; Fritea, L.; Marian, I.O.; Indrea, E.; Walcarius, A.; Săndulescu, R. Tetrabutylammonium-modified clay film electrodes: Characterization and application to the detection of metal ions. Talanta 2014, 125, 36-44.

20. Park, Y.; Ayoko, G.A.; Frost, R.L. Application of organoclays for the adsorption of recalcitrant organic molecules from aqueous media. J. Colloid Interface Sci. 2011, 354, 292-305.

21. Park, Y.; Suna, Z.; Ayoko, G.A.; Frost, R.L. Bisphenol A sorption by organomontmorillonite: Implications for the removal of organic contaminants from water. Chemosphere 2014, 107, 249-256.

22. Cabrera, A.; Trigo, C.; Cox, L.; Celis, R.; Cornejo, J. A comparative study of the use of organoclay-based formulations and organic amendment to reduce the leaching of theherbicide MCPA in soil. Clean-Soil Air Water 2008, 36, 990-995.

23. He, H.; Ma, L.; Zhu, J.; Frost, R.L.; Theng, B.K.G.; Bergaya, F. Synthesis of organoclays: A critical review and some unresolved issues. Appl. Clay Sci. 2014, 100, $22-28$.

24. Park, Y.R. Synthesis, characterisation and application of organic surfactants modified clays for water purification, $\mathrm{PhD}$ Thesis, Queenland University of Technology, Brisbane Australia, 2013.

25. Ogawa, M.; Handa, T.; Kuroda, K.; Kato, C. Formation of organoammoniummontmorillonites by solid-solid reactions. Chem. Lett. 1990, 19, 71-74.

26. Khaorapapong, N.; Ogawa, M. In situ formation of bis(8-hydroxyquinoline) zinc(II) complex in the interlayer spaces of smectites by solid-solid reactions. J. Phys. Chem. Solids 2008, 69, 941-948.

27. Ogawa, M.; Kato, K.; Kuroda, K.; Kato, C. Preparation of montmorillonite alkylamine intercalation compounds by solid-solid reactions. Clay Sci. 1990, 8, 31-36.

28. Khaorapapong, N.; Ontam, A.; Ogawa, M. Very slow formation of copper sulfide and cobalt sulfide nanoparticles in montmorillonite. Appl. Clay Sci. 2011, 51, 182-186.

29. He, H.; Ma, Y.; Zhu, J.; Yuan, P.; Qing, Y. Organoclays prepared from montmorillonites with different cation exchange capacity and surfactant configuration. Appl. Clay Sci. 2010, $48,67-72$. 
30. Cubuk, O.; Caglar, B.; Topcu, C.; Coldur, F.; Sarp, G.; Tabak, A.; Sahin, E. Structural characterization of hexadecyltrimethylammonium-smectite composites and their potentiometric electrode applications. Appl. Surf. Sci. 2015, 338, 99-112.

31. Caglar, B.; Topcu, C.; Coldur, F.; Sarp, G.; Caglar, S.; Tabak, A.; Sahin, E. Structural, thermal, morphological and surface charge properties of dodecyltrimethylammoniumsmectite composites. J. Mol. Struct. 2016, 1105, 70-79.

32. Chen, X.; Hu, N.; Zeng, Y.; Rusling, J.F.; Yang, J. Ordered electrochemically active films of hemoglobin, didodecyldimethylammonium ions, and clay. Langmuir.1999, 15, 7022-7030.

33. Korichi, S.; Elias, A.; Mefti, A. Characterization of smectite after acid activation with microwave irradiation. Appl. Clay Sci. 2009, 42, 432-438.

34. Bergaya, F.; Vayer, M. CEC of clays: Measurement by adsorption of a copper ethylenediamine complex. Appl. Clay Sci. 1997, 12, 275-280.

35. Stålhandske, C.M.V.; Persson, I.;Sandström, M.; Kamienska-Piotrowicz, E. Structure of the solvated zinc(II), cadmium(II), and mercury(II) ions in $N, N$-dimethylthioform-amide solution. Inorg. Chem. 1997, 36, 3174-3182.

36. Tetsuka, H.; Katayama, I.; Sakuma, H.; and Tamura, K. Effects of humidity and interlayer cations on the frictional strength of montmorillonite. Earth Planets Space 2018, 70, 1-9.

37. Zhang, Z.; Zhang, J.; Liao, L.; Xia, Z. Synergistic effect of cationic and anionic surfactants for the modification of Ca-montmorillonite. Mater. Res. Bull. 2013, 48, 1811-1816.

38. Benguella, B.; Yacouta-Nour, A. Elimination des colorants acides en solution aqueuse par la bentonite et le kaolin. C. R. Chim. 2009, 12, 762-771.

39. Yevtushenko, T.V.; Tonkha, O.L.; Pikovskaa, O.V. Changes in balk density and porosity of chernozem typical under different cultivation systems. Ann. Agrar. Sci. 2016, 14, 299-302.

40. Gammoudi, S.; Frini-Srasra, N.;Srasra, E. Influence of exchangeable cation of smectite on HDTMA adsorption: Equilibrium, kinetic and thermodynamic studies. Appl. Clay Sci. 2012, 69, 99-107.

41. Xi, Y.; Ding, Z.; He, H.; Frost, R.L. Structure of organoclays an X-ray diffraction and thermogravimetric analysis study. J. Colloid Interface Sci. 2004, 277, 116-120.

42. Zhou, Q.; Frost, R.L.; He, H.; Xi, Y.; Liu, H. Adsorbed paranitrophenol on HDTMAB organoclay A TEM and infrared spectroscopic study. J. Colloid Interface Sci. 2007, 307, 357-363.

43. Zhou, Q.; Frost, R.L.; He, H.; Xi, Y. Changes in the surfaces of adsorbed paranitrophenol on HDTMA organoclay - The XRD and TG study. J. Colloid Interface Sci. 2007, 307, 50-55.

44. Kamitori, S;. Sumimoto, Y.; Vongbupnimit, K.; Noguchi, K.; Okuyama, K. Molecular and crystal structures of dodecyltrimethylammonium bromide and its complex with $p$ phenylphenol. Mol. Cryst. Liq. Cryst. 1997, 300, 31-43.

45. Lagaly, G.; Ogawa, M.; Dékány, I. Handbook of Clay Science, Chap 7.3: Clay mineral organic interactions, Vol . 1, 1st eds., Dev. Clay Sci. Elsevier: Amsterdam; 2006, 309-330.

46. Madejová, J. FTIR techniques in clay mineral studies. Vib. Spectrosc. 2003, 31, 1-10.

47. Madejová, J.; Bujdak, J.; Janek, M.; Komadel, P. Comparative FT-IR study of structural modifications during acid treatment of dioctahedral smectites and hectorite. Spectrochim. Acta A Mol. Biomol. Spectrosc. 1998, 54, 1397-1406.

48. Vicente-Rodriguez, M.A.; Suarez, M.; Banares-Munoz, M.A.; Lopez-Gonzalez, J.D. Comparative FT-IR study of the removal of octahedral cations and structural modifications during acid treatment of several silicates. Spectrochim. Acta A Mol. Biomol. Spectrosc. 1996, 52, 1685-1694.

49. Silva, M.R.; Beja, A.M.; Paixao, J.A. Pseudosymmetry in tetradecyltrimethylammonium bromide. Acta Cryst. 2003, E59, o1151-o1152.

50. Campanelli, A.R.; Scaramuzza, L. Hexadecyltrimethylammonium bromide. Acta Cryst. 1986, C42, 1380-1383. 